(C)2018, Elsevier. Licensed under the Creative Commons Attribution-NonCommercialNoDerivatives 4.0 International http://creativecommons.org/about/downloads

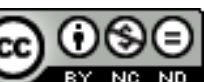




\title{
A review of non-invasive insulin delivery systems for diabetes therapy in clinical trials over the past decade
}

Najma Easa, Raid Alany, Mark Carew, Anil Vangala*

School of Life Sciences, Pharmacy \& Chemistry, Kingston University London, KT1 2EE, UK

\begin{abstract}
At present, the main form of insulin administration is the invasive subcutaneous route, and this for many individuals means managing their glucose levels with multiple daily injections, which is both painful and difficult to administer chronically. To increase patient compliance, products are slowly reaching the market that are more patient friendly such as the insulin patch-pump systems, like Omnipod and V-Go, but also the inhaled insulin Afrezza ${ }^{\circledR}$ and the buccal insulin Oral-lyn ${ }^{\text {TM }}$. This review outlines the history of insulin, the various options that are currently available in practice for insulin delivery, and the non-invasive delivery systems that have managed to enter the different stages of clinical trials in the past decade.
\end{abstract}

\section{Keywords}

Non-invasive; Insulin; Diabetes; Clinical trials; Buccal; Transdermal; Nasal; Pulmonary; Oral.

*Corresponding author telephone no:

0044 (0)208417 2738 


\section{Introduction}

Diabetes Mellitus is a metabolic disease characterised by deficiency or development of resistance to insulin or in some cases both. In 2012, around 1.5 million deaths were caused by the disease and according to the 2016 WHO Global report on diabetes the estimated number of adults with the condition increased considerably from 108 million in 1980 to 422 million in 2014 [1]. It was predicted by Wild et al. that a total of 366 million people would be with diabetes in 2030, but based on the International Diabetes Federation (IDF) this prediction was already reached in 2011, and it was estimated by 2030 the number would be much greater with as many as 552 million adults [2,3]. In the latest estimation, published in 2018 and shown in Table 1, the IDF estimated the number of adults (aged 18-99 years) with diabetes to be 451 million, in 2017, and the projection for 2045 is a substantial increase to 693 million [4].

\begin{tabular}{|l|l|l|}
\hline \multicolumn{3}{|l|}{ Table 1. Estimated number and prevalence of adults with diabetes [4]. } \\
\hline Year & Number (millions) & Prevalence of adults (\%) \\
\hline 2017 & 451 & $8.4 \%$ \\
\hline 2045 & 693 & $9.9 \%$ \\
\hline
\end{tabular}

Currently, for insulin-dependent diabetic patients, the main route of insulin administration is the parenteral route of administration. For individuals to maintain the correct level of blood glucose in many cases this requires them to chronically administer multiple daily injections of either long-acting, intermediate-acting, short-acting and/or rapid acting insulin via the subcutaneous route. To increase patient compliance, and to reduce the burden of daily painful administration of insulin, many researchers are working on the development of novel carrier systems for the safe and effective delivery of insulin via non-invasive routes, which mainly include; buccal, oral, pulmonary, nasal and transdermal systems. This review summarizes the options that are currently in practice for insulin delivery, including Oral-lyn ${ }^{\mathrm{TM}}$ and Afrezza ${ }^{\circledR}$, but the key component of the review covers non-invasive delivery formulations that have managed to enter the various stages of clinical trials in the past decade $[5,6]$. The information is primarily based on the database, ClinicalTrials.gov, which is a database of clinical studies taking place worldwide and conducted with human participants [7].

\subsection{Diabetes mellitus}

The WHO classifies diabetes mellitus into: type 1, type 2, gestational diabetes and intermediate conditions such as impaired glucose tolerance and impaired fasting glycaemia, which can progress into diabetes [1]. The two main types of diabetes mellitus are type 1 diabetes (T1DM) and type 2 diabetes (T2DM). The aetiology of both T1DM and T2DM is complex and based on current evidence involves both genetic and environmental factors [8]. T1DM, also known as early onset, insulin-dependent or juvenile diabetes, is caused by absolute deficiency of insulin as a result of autoimmune destruction of the insulin producing beta-cells in the pancreas. Around one tenth or less of all diabetics are classified as type 1 diabetics and are diagnosed commonly in early childhood or as young adults. T2DM is the most common form of diabetes, also known as late onset or non-insulin-dependent diabetes, which is responsible for almost all the other cases of diabetes and is caused because of insulin resistance and relative insulin deficiency.

In epidemiological studies, fasting blood plasma glucose of $\geq 7 \mathrm{mmol} / \mathrm{L}$ or $\geq 126 \mathrm{mg} / \mathrm{dL}$ is accepted for diagnosis of diabetes as per the 1999 WHO criteria [9]. Uncontrolled diabetes in the short-term can result in dangerous complications such as hypoglycaemia (less than $4 \mathrm{mmol} / \mathrm{L}$ ), hyperosmolar 
hyperglycaemic state (often over $40 \mathrm{mmol} / \mathrm{L}$ ) and diabetic ketoacidosis. In the long-term, diabetic patients, often experience other medical problems including cardiovascular disease, kidney failure, loss of vision and neuropathy leading to possible leg amputations [1]. The Diabetes Control and Complications Trial (DCCT) was able to demonstrate that intensive insulin therapy can delay microvascular complications, such as retinopathy and nephropathy in type 1 diabetic patient, and the benefits remain for at least four years thereafter [10-12]. On the other hand, in clinical practice, one of the drawbacks of controlling blood glucose levels too strictly is the increased risk of hypoglycaemic episodes.

\subsection{History of insulin}

In 1923, two years after the discovery of insulin by Banting and Best, the company Eli Lilly, in partnership with the university of Toronto, managed to produce large-scale purified animal insulin, which resulted in record profits for the company $[13,14]$. During the first 60 years of the discovery of insulin, optimisation efforts focused on isolation of insulin from animal sources, primarily from bovine and porcine pancreata. But later in 1982, after regulatory approval of the world's first recombinant DNA drug, Humulin (human insulin), by the United Kingdom, United States, West Germany and the Netherlands, the focus on purification processes shifted towards mainly enhancing properties of insulin through changes in both the formulation and amino acid composition [15]. In 1996, Eli Lilly and company also developed the first commercial insulin analogue, insulin lispro (Humalog), by altering the naturally occurring amino acids in positions 28 and 29 of the B-chain to form Lys (B28) and Pro (B29) human insulin $[15,16]$.

In the 21st century, a variety of insulin types are now in clinical practice and the amino acid sequence of the insulin differs depending on whether the insulin is human insulin, bovine insulin, porcine insulin or analogues of human insulin. Although now bovine insulin is rarely used since the main method of production is with recombinant DNA technology using bacteria and yeast [17]. After FDA approval of Pfizer's inhaled insulin product Exubera in 2006, even though the invention was unsuccessful, the main efforts now appear to be on producing alternative non-invasive formulations of insulin or analogues with transformed properties [18]. The two recent successful developments in the area, both developed by Novo Nordisk Limited, include approval of the longer-acting insulin degludec (Tresiba) injections by the FDA and European Medicines Agency (EMA) and the most recent ultra-fast rapidacting insulin aspart injections known as Fiasp approved by the EMA [19-21]. Fiasp is both faster and more stable compared to the conventional insulin aspart (Novorapid ${ }^{\circledR}$ or NovoLog ${ }^{\circledR}$ ) due to the addition of two extra excipients, nicotinamide and arginine, and hence it is suggested to result in insulin release more reflective of physiological insulin [22].

\subsection{Structure, biosynthesis and properties of insulin}

The monomeric human insulin, with a molecular weight of $5.8 \mathrm{kDa}$, comprises 51 amino acids, which is in the form of an $A$ chain of 21 amino acids and a $B$ chain of 30 amino acids. As shown in Figure 1 , two disulphide bonds connect the $A$ and $B$ chains (A7-B7 \& A20-B19) and one disulphide linkage is present within the A chain (A6-A11) [23,24]. Insulin in its primary form exists as a chain of 110 amino acids, known as preproinsulin, which is translated from insulin mRNA in the cytosol of pancreatic $\beta$ cells $[23,25]$. There are several factors that control the biosynthesis of insulin, glucose metabolism being the central event, which results in the stimulation of insulin gene transcription and mRNA translation [26]. 


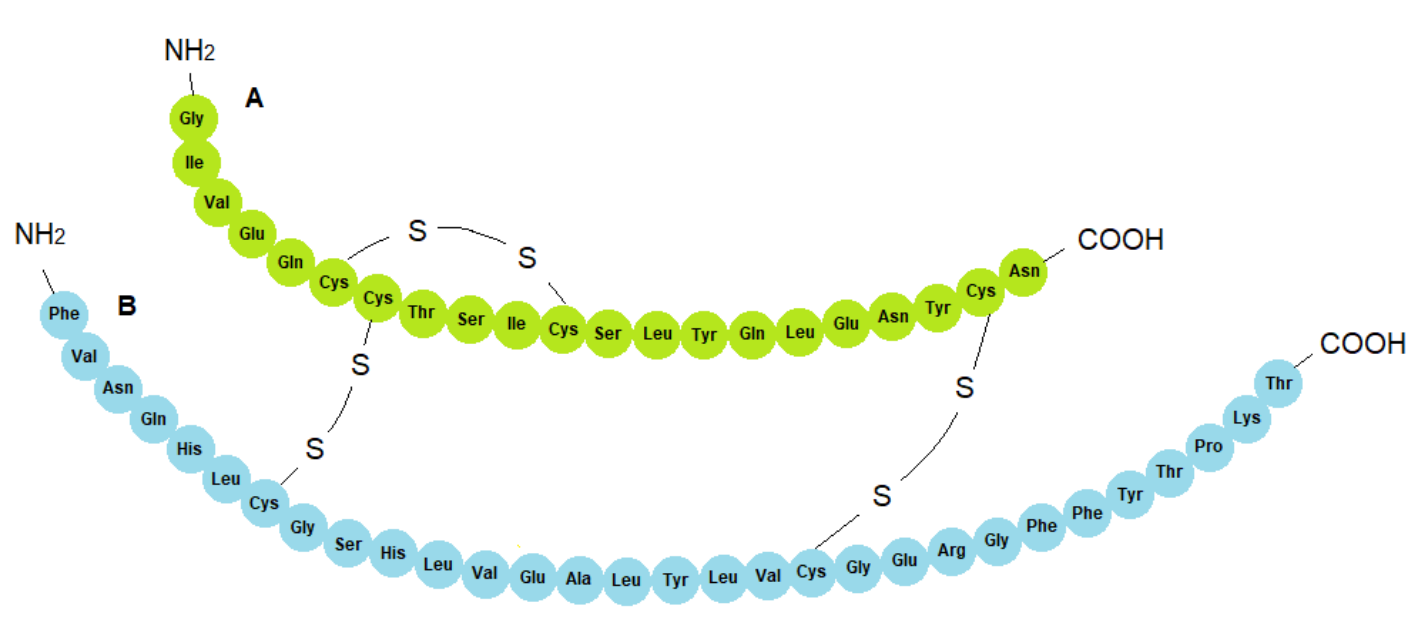

Figure 1: Schematic representation of human insulin comprising of 51 amino acids, which is in the form of an $A$ chain of 21 amino acids and a B chain of 30 amino acids. Two disulphide bonds connect the $A$ and $B$ chains (A7-B7 \& A20-B19) and one disulphide linkage is present within the $A$ chain (A6-A11) $[23,24]$.

During biosynthesis of insulin, the interaction of the signal peptide of preproinsulin with the cytosolic ribonucleoprotein signal recognition particle (SRP) facilitates the translocation of the molecule across the endoplasmic reticulum (ER) membrane to the luminal side of the rough ER $[23,27,28]$. In this process, the 24 amino acids signal peptide is cleaved off by signal peptidases, which results in the formation of the 86 amino acid long proinsulin consisting of the B chain, C peptide and A chain $[17,29,30]$. Within the ER, proinsulin obtains the disulphide linkages, and the required threedimensional structure for its function.

Proinsulin transportation from the ER to the Golgi apparatus occur via secretory vesicles and both guanosine-5-triphosphate (GTP) and calcium are required for the process [8,31]. As comprehensively reviewed by Dunn et al. 2005 in the storage/secretory vesicles of the Golgi apparatus proinsulin starts forming zinc and calcium containing dimers and then hexamers. Hence the vesicles serve as storage sites for insulin and the C-peptide. In the secretory vesicles, enzymes remove the C-peptides of proinsulin to produce mature insulin hexamers, which leads to crystallization of the hexamers due to mature insulin being less soluble compared to proinsulin $[8,23,32]$. Insulin secretion from the pancreatic $\beta$-cells occurs when the plasma membrane of the storage vesicles fuses with the cell membrane in response to high plasma glucose levels. The release of the crystallised insulin hexamers from the vesicles in the intercellular space results in the crystals dissolving and releasing the biologically active insulin monomers [32].

\section{Routes of insulin delivery}

The aim of insulin therapy, in insulin dependent diabetics, would be to achieve plasma insulin levels that mimic as closely as possible the normal secretion of insulin in non-diabetic individuals. This means covering both the release of basal or baseline insulin, typically in the range of 5 to 15 microunits per millilitre, and insulin released in response to meal intake, which generally results in peak serum insulin levels of 60 to 80 microunits per millilitre [17,33]. Since the original discovery of the hormone, the main method of insulin administration has been via subcutaneous (sc) injections. Figure 2 shows some 
of the various routes of insulin delivery that currently exist and some routes of delivery that are under investigation in clinical trials and will be discussed in this review.

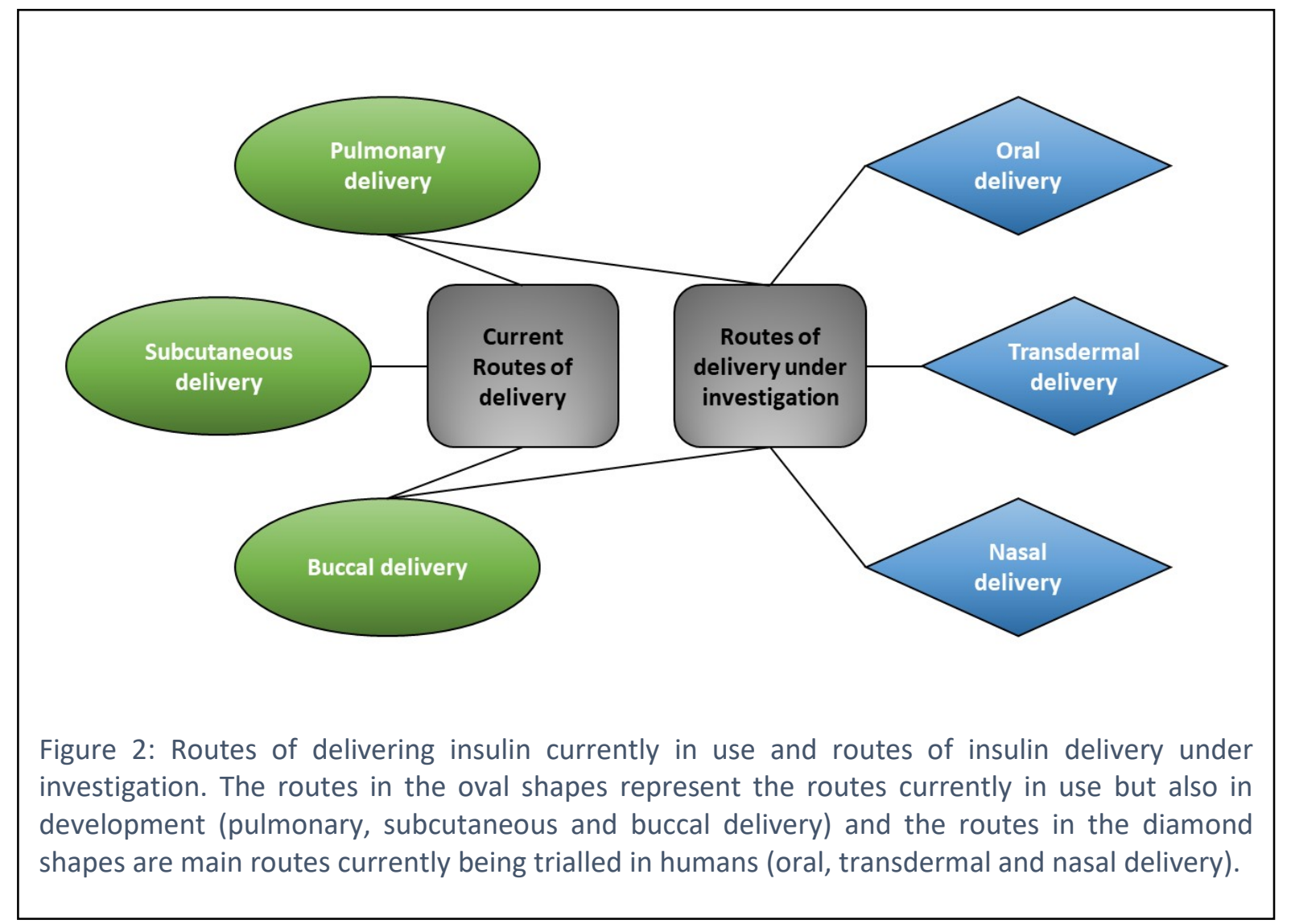

\subsection{Insulin therapy currently in clinical practice}

Modern subcutaneous administration devices are safer, offer more accurate dosing and have less complications compared to the original use of vials; where patients had to draw the prescribed doses of insulin from the vials using separate syringes. The innovation of the first pen injector, NovoPen ${ }^{\circledR}$ in 1985, was a success and now the main form of insulin administration is through the use of pen devices, although the original pen device had to be refilled using disposable insulin cartridges, the injection pens that are now in more common practice are the completely disposable injection pens such as FlexPen ${ }^{\circledR}$ by Novo Nordisk A/S and SoloStar ${ }^{\circledR}$ by Sanofi-Aventis [34]. The main advantages of sc insulin therapy include the high bioavailability, the relatively controlled onset of action and the flexibility in dosing. The disadvantages include the risk of lipodystrophy, painful administration, bruising of injection sites, weight gain and alterations in absorption when the injected limb is used for strenuous exercise. In terms of time profile, the onset of action of short-acting insulins, i.e. soluble or regular insulins, are around 30-60 minutes, maximal effect occurs at 2-4 hours, and it lasts for up to 8 hours. Rapid-acting insulins, compared to regular insulin, are faster in onset and have a shorter duration of action. The intermediate acting formulations, such as isophane human insulin (Humulin I), and longacting preparations, such as insulin glargine (Lantus), have an onset of action of 1-2 hours, peak levels are reached around 4-12 hours, and have a duration of action of 16-42 hours [35]. 


\subsection{Subcutaneous insulin patch-pump systems}

Using a similar concept to the continuous subcutaneous insulin infusion (CSII) systems, companies are now developing more discreet and convenient devices, labelled as the patch-pump systems, which do not involve attachment of tubes [36]. Omnipod is such a device and is available in places such as the USA, UK, Germany and Israel [37]. The system comes in two parts a small Pod, that is the insulin reservoir (200 units of insulin) and delivers insulin via a discreet needle, and a handheld Personal Diabetes Manager (PDM), which uses wireless communication to deliver basal insulin continuously. The Pod can provide up to 72 hours of insulin [37].

One of the most simplistic of the patch systems is the $\mathrm{V}-\mathrm{Go}^{\mathrm{TM}}$ device designed by Valeritas, Inc. as it does not require batteries, programming or a hand-held remote [38]. The daily disposable $\mathrm{V}-\mathrm{Go}^{\mathrm{TM}}$ insulin delivery device is designed to deliver a 24-hour cover of both basal and bolus insulin and is suitable for patients on multiple daily injections. The V-Go device is loaded by the patient with U-100 rapid-acting insulin analogue, compatible with both Humalog (insulin lispro) and NovoLog (insulin aspart), using the adapter (EZ fill), which is provided with every 30-day supply of the devices. The device is small, lightweight ( 1 ounce) and waterproof; after loading, the patient can attach the device comfortably and discreetly on the skin of their abdomen, arms or thighs via the hypoallergenic adhesive strip [39]. To improve patient comfort, floating needle ${ }^{T M}$ technology is used, which allows movement of the needle relative to the device. The push of a button allows the floating needle (30gauge and $4.6 \mathrm{~mm}$ ) to be inserted into the subcutaneous tissue, which starts the basal infusion of insulin for the whole 24-hour period. The basal rates are pre-set and are available as 20, 30 or 40 units of insulin per 24-hours and each one also allows for 36 units of bolus insulin daily. The meal-time administration of insulin is initiated by the patient by two simple sequential clicks of the bolus ready and bolus delivery buttons. The device was launched by Valeritas, Inc. in May 2012 [38].

\section{Evaluation of insulin delivery via non-invasive routes}

Subcutaneous administration of insulin has some advantages; but being an invasive technique alternative routes of administration are being investigated. Although there are other non-invasive routes, including vaginal, rectal and ocular, Figure 3 shows a summary of the advantages and disadvantages of the main routes being investigated and those are the routes that will be discussed here in this review. 


\section{Buccal Delivery}

$\checkmark$ Good patient acceptability

$\checkmark$ Convenient and easily removed in the event of adverse reactions, side-effects or over dosage

$\checkmark$ Low enzymatic activity compared to GIT

$\checkmark$ Highly vascularized absorptive surface area

$\checkmark$ Fast flowing blood supply $\left(2.4 \mathrm{ml} / \mathrm{min} / \mathrm{cm}^{2}\right)$

$\checkmark$ Direct access to the systemic circulation

$\checkmark$ Potential bypass of hepatic first pass metabolism through the internal jugular vein

$\checkmark$ Short recovery time after trauma or injury

$\checkmark$ Tolerant to possible allergens due to low number of Langerhans cells

$X$ Small surface area for absorption

$X$ Low permeability

$X$ Saliva secretions can vary (excessive secretion can dilute the drug or cause wearing away of formulation \& too little maybe inadequate to cause dissolution of the formulation)

$X$ Taste of drug can be an issue

$X$ Possible choking hazard due to unintentional swallowing of formulation

$X$ Food consumption may dislodge delivery system

$\mathrm{X}$ Drinking hot, cold or acidic liquids may alter drug absorption from formulation

\section{Oral Delivery}

$\checkmark$ Most patient friendly route of drug delivery

$\checkmark$ Convenient administration hence possible improvement in compliance

$\checkmark$ More reflective of physiological insulin delivery

$\checkmark$ Reduced peripheral hyperinsulinemia

$\checkmark$ Possibly reduced chance of weight gain

$\mathrm{X}$ Low stomach $\mathrm{pH}$ leading to insulin degradation

$X$ Low permeability

$X$ Enzymatic degradation in the GIT

$X$ Variability of drug absorption in the GIT depending on location of release in the GIT, the fed and fasted state and transit time

$X$ First pass hepatic insulin extraction leading to degradation of $50 \%$ or more of insulin that enters hepatocytes

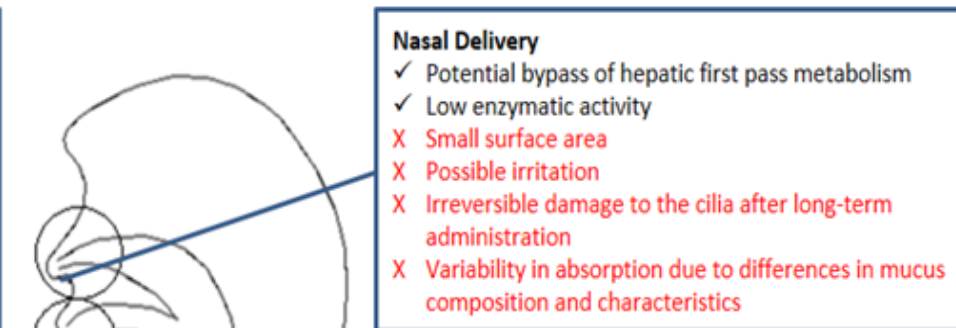

Potential bypass of hepatic first pass metabolism

Low enzymatic activity

ill surface area

Possible irritation administration composition and characteristics

Figure 3: Summary of advantages and disadvantages of the main five non-invasive delivery routes (buccal, oral, nasal, pulmonary and transdermal) for insulin delivery based on information from several reviews [40-48].

\subsection{Pulmonary insulin delivery}

Of the inhaled insulin products that have reached clinical trials, only two products, both dry powder inhaler (DPI) systems, have secured FDA approval; one being Exubera, which also had the EMA approval in Europe, and Afrezza ${ }^{\circledR}[18,49,50]$. In 2007, the withdrawal of Exubera from the market by Pfizer led to a number other companies, such as Novo Nordisk and Eli Lilly, to discontinue the development of their inhaled insulin products around the same time [18]. As reviewed by Heinemann (2008) Exubera was unsuccessful due to mainly the design of the device not taking into consideration the consumers perspectives. Though theoretically envisioned well for the purpose, in practice, the device was large and bulky, hence, difficult for patients to carry around and could not be used with discretion. Other factors that contributed to the failure of Exubera include; the unimpressive 
launching of the product, the training required to use the device, the high cost of the product, difficult dosing equivalence, the requirement for patients to regularly check their lung function and safety concerns with chronic use of the product [18].

However, another inhaled insulin product is currently in clinical trials, referred to in Table 2 , it is the pocket-sized insulin inhaler device Dance-501, which uses a vibrating mesh micropump technology developed by Aerogen [50]. The device, shown in Figure 4, appears to have some potential for achieving pulmonary insulin delivery, based on the recent completion of phase 2 clinical trials. The advantages of the Dance-501 is that it is small, discrete, portable and battery operated and hence the developers have overcome the disadvantages faced with Exubera, produced by Pfizer [50]. Additionally, due to the formulation being a liquid aerosol system, the incidence of coughs is lower, compared to DPI systems, and the price of using this device is said to be comparative to current subcutaneous pen devices [50]. One of the possible drawbacks of the design is that the insulin release is breath actuated, which, without good initial training, could result in fluctuating bioavailability like current problems faced with such inhaler devices used for respiratory diseases. Another weakness is that prior to administration, precise volumes of the formulation from a separate container is required to be dispensed into the inhaler reservoir, which adds another step to the administration process and the manual work required for the process could be a problem for arthritic and very elderly patients. There are limited studies available for bioavailability of the formulation for the Dance-501 device but a study completed with 24 type 2 diabetic patients with a previous device, called Aerodose using Aerogen's electronic aerosol generator technology, showed

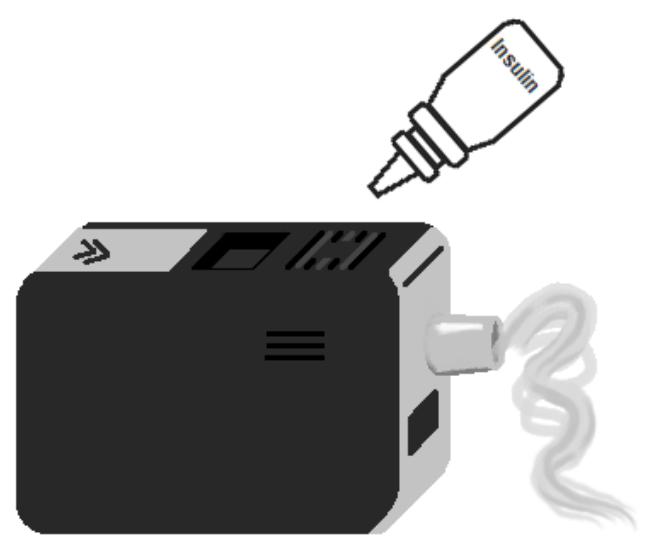

Figure 4: Simplified image of the Dance-501 device along with a separate insulin container. This device uses a vibrating mesh micropump technology developed by Aerogen; figure adapted from [50]. no significant difference in the relative bioavailability and relative biopotency of inhaled insulin to subcutaneous administration of insulin among doses used at fixed ratios [51]. It was found to obtain overlapping dose-response curves with inhaled and subcutaneously administered insulin. The amount of inhaled insulin to be administered was required to be 10 times greater than the subcutaneous dose e.g. 160 units of inhaled insulin was roughly equivalent to 16 units administered using subcutaneous injections. The positive outcome from the study also was the fact that the inhaled formulation reached maximum serum insulin $\left(T_{\max }\right)$ concentration significantly $(P<0.001)$ faster compared to subcutaneous insulin administration, which may be explained by the high permeability across the thin alveolarcapillary barrier. Moreover, in terms of lung function no serious adverse events or clinically relevant changes were observed. Overall, this could be one of the promising formulations to look out for in the near future.

\subsection{Buccal insulin delivery}

Apart from Generex Oral-lyn ${ }^{\mathrm{TM}}$, mentioned below, another interesting new buccal formulation is the formulation developed by the joint partnership of MonoSol Rx and Midatech Ltd [47]. The two companies have combined their specialities, Midatech's gold nanoparticle (GNP) technology and MonoSol's Pharmfilm drug delivery technology, to form a buccal soluble film product called MidaForm ${ }^{\circledR}$ Insulin PharmFilm [52,53]. In this formulation, the recombinant human insulin is bound to 
glycan-coated gold nanoparticles through non-covalent binding and embedded in a polymeric mucoadhesive film for delivery of insulin via the buccal mucosa. It is claimed by Midatech Pharm that the gold nanoparticle technology helps drugs with permeability through membranes, leads to an increase in stability. The particles are also inert and biocompatible [54]. Gold metal atoms form the core of the GNPs and these are attached via gold sulphur bonds to an organic layer of glycans. During the self-formation process insulin, can attach to the gold core, which is 1-2 nanometers in size. In Phase I clinical trials, using insulin aspart, the formulation was shown to be both well tolerated and safe [47]. Additionally, owing to their small size GNPs are believed to be eliminated via the liver and kidneys. Although the technology looks promising, and the company has facilities to scale up the production of the formulation, Midatech made an announcement in May 2016 that the results of the phase 2a clinical trials (MTD101) demonstrated low bioavailability for the transbuccal film insulin compared to subcutaneous insulin and hence the company were evaluating their options [55]. The product is not on the pipeline list of products for Midatech or MonoSol Rx, now renamed as Aquestive. It is less likely that the development of MidaForm ${ }^{\circledR}$ Insulin PharmFilm will be advanced.

\subsection{Oral insulin delivery}

Novo Nordisk in partnership with Merrion Pharmaceuticals are developing the GIPET (gastrointestinal permeation enhancement technology) system for oral delivery of insulin in the form of a tablet [56]. The oral preparation consists of micelles formed with the aid of patented absorption enhancers, which have the purpose of increasing absorption across the GI tract. The GIPET formulation in addition to having good reproducibility, as stated by the CEO of Merrion Pharmaceuticals, due to the use of GRAS ingredients will also result in the development of oral products that are low risk and have good safety profiles. The main product is known as GIPET I (OI338GT or NN1953), a long-acting insulin analogue, which has managed to reach phase 2 clinical trials. Novo Nordisk are also using the GIPET technology to develop oral formulations of two other insulin analogues known as insulin 287 and insulin 320 (OI320GT or NN1957), which have both completed phase 1 clinical trials [57]. Other than the basic information not much can be found about the GIPET formulation or the results of the trials.

Oramed Pharmaceuticals have an oral insulin formulation, known as the ORMD-0801 capsule, which is being tested in several phase 2 clinical trials in both type 1 and type 2 diabetic patients [58]. Oramed Pharmaceuticals' Protein Oral Delivery ${ }^{\mathrm{TM}}$ (POD) technology consists of an enteric coated capsule that encompasses insulin along with protease inhibitors and absorption enhancers that aid delivery in the small intestine. In the phase 2 trial (NCT00867594), eight type 1 diabetic patients, with uncontrolled blood glucose levels (HbA1c: 7.5-10\%), were trialled with the ORMD-0801 capsules containing 8mg of insulin in each capsule [59]. In this trial, the patients were asked to self-administer the ORMD-0801 capsules three times a day, 45 minutes before their meals, in addition to their standard insulin therapy. Although the study included a small number of individuals, and a short treatment period of 10 days, the outcome was significantly reduced glycaemia throughout the day. Additionally, the formulation was tolerated well by the individuals with no hypoglycaemic episodes or adverse events. One of the potential drawbacks to this formulation is the administration of large amount of insulin and it is surprising that no hypoglycaemic episodes occurred within the study, but the study was small and the effects of interindividual variability will more likely be experienced in larger studies.

Diasome pharmaceuticals have designed an oral HDV (hepatocyte-directed vesicle) insulin gel capsule, in which all the insulin is bound to HDV. The HDV vesicle is less than $150 \mathrm{~nm}$ in diameter and the phospholipid bilayer has specific hepatocyte-targeting molecule (HTM), which in their latest preparation is biotin-phosphatidylethanolamine (biotin-PE), incorporated within its structure [60]. As reviewed by Geho et al. this formulation not only improves oral insulin delivery by shielding insulin from proteolytic enzymes in the upper GI tract, but additionally it is more able to mimic physiological insulin delivery via HTM guidance towards hepatocytes. This novel carrier system looks promising and 
it has been approved by the FDA for initiation of phase 3 clinical trials based on the effectiveness of the delivery system in phase 2 human studies. In comparison to other possible oral insulin formulations, one of the most promising aspects of this formulation is the amount of insulin contained in each capsule, which can be as little as 5 units $[43,61]$. Accuracy of dosing is highly important with insulin treatment and one of the main disadvantages with insulin being given orally is the possibility that interindividual variability can lead to overdosing, due to both genetic variations in individuals but also factors such as food and transit time in the GI tract, which in theory the risk would be much lower with formulations containing smaller amounts of insulin; such as with HDV oral insulin compared to formulations with 150 units or more per dose, such as Capsulin ${ }^{T M} I R$ designed by Diabetology [62].

Oshadi Drug Administrations' newest formulation is in phase II clinical trials and it has been called Oshadi Icp, as it is a combination of insulin, proinsulin and C-peptide. In 2010, the company made a patent application for their oral insulin formulation in which it is stated that the preparation comprises "a particulate non-covalently associated mixture of pharmacologically inert silica nanoparticles having a hydrophobic surface, a branched polysaccharide, and insulin suspended, embedded or dispersed in an oil or mixture of oils" [63]. The diameter of the nanoparticles is in the range of 1-100 nanometers. Other than the information obtained from the patent (20100278922) there is very little information published by the company. The possible reasoning behind the combination of insulin, proinsulin and C-peptide in the formulation is to reflect a delivery system similar to endogenous insulin release particular as orally delivery insulin reaches the circulation via the hepatic portal vein [64].

Biocon Limited's oral insulin tablet IN-105, now known as Tregopil, is a novel insulin analogue [65]. Tregopil is a modified form of human insulin where the free amino acid group on the Lys- $\beta 29$ residue has been covalently bonded via a non-hydrolysable amide bond to a small polyethylene glycol (PEG) molecule [66]. This modification, in comparison to the original human insulin, has the advantage of better stability and reduced degradation in the presence of enzymes in the GIT possibly due to steric hindrance. The water solubility of the insulin analogue is also improved and is most likely attributed to the presence of the PEG modification. Furthermore, in phase I studies it was found that the amount of insulin absorbed was adequately significant to cause reductions in plasma glucose levels, which indicated that the alteration aided absorption of the intact insulin peptide in the GIT. After administration, based on the initial studies, it was observed that insulin levels peaked at around 20 minutes and returned to baseline after 1 hour and 20 minutes, which indicates Tregopil could possibly be useful for control of postprandial glucose levels [66].

Diabetology (not included in the clinicaltrials.gov search table) is also one of the companies that is developing an oral insulin product, known as Capsulin ${ }^{\top \mathrm{M}} \mathrm{IR}$ (insulin replacement), which is in the phase 2 stage of clinical trials [67]. The insulin (150U or 300U) in the formulation is unmodified and the formulation is a simple mixture contained in a standard enteric coated capsule [62]. The oral formulation uses the company's in-licensed Axcess ${ }^{\mathrm{TM}}$ drug delivery technology, which contains a solubilizer and absorption enhancer but does not include any new chemical entities (NCEs) and has demonstrated effectiveness in delivering peptides such as insulin [68]. The main excipients are both pharmacopoeial and GRAS listed and include an aromatic alcohol and dissolution aid. The whole formulation has been designed to bypass the harsh $\mathrm{pH}$ conditions of the stomach and to rapidly dissolve in the small intestine (jejunum) allowing all the components to meet the surface of the intestinal wall.

Bows Pharmaceutical AG were also developing an oral insulin formulation consisting of insulin in a dextran matrix capsule, but it appears that they are no longer active in developing the product with the last update being November 2010 [7]. 
As insulin is hydrophilic, the main route of permeation in the Gl tract is via the paracellular route [69]. Being a protein, the permeability of insulin as well as the oral bioavailability, is likely to be extremely low without any absorption enhancement [70]. Therefore, most of the oral insulin formulations being developed include absorption enhancers but the likely toxicity of such products is a concern in the long term.

\subsection{Nasal insulin delivery}

CPEX Pharmaceuticals Inc. has developed an intranasal insulin spray, containing regular short-acting human recombinant insulin, given the trade name Nasulin ${ }^{\mathrm{TM}}$. The main excipient in the nasal insulin formulation is the cyclopentadecalactone (CPE-215), which according to the company has been proven to enhance absorption and is known as the permeation enhancement technology of CPEX $[71,72]$. CPE-215 is a naturally occurring compound obtained from the plant Angelica archangelica and is contained in many everyday use products including food ingredients, cosmetics and personal hygiene. The other components of the formulation include polysorbate 20 , sorbitan monolaurate and cottonseed oil. During the initial studies in healthy volunteers, it was found that the normal physiological nasal cycle did not result in clinically significant alterations in insulin absorption but the absorption of insulin was decreased by roughly $50 \%$ in those individuals that were affected by total nostril blockage [73]. Insulin levels peak at around 10-20 minutes post administration and hence the formulation is suitable for prandial glucose control. Nasulin ${ }^{\mathrm{TM}}$ is generally well tolerated although transient side-effects such as irritation, tickling sensation and sneezing do occur but tend to disappear on continued dosing. In the study by Stote et al. 2011 it was concluded that overall the intrasubject variability of insulin administered using Nasulin was approximately $40 \%$, which is comparable to that of normal subcutaneous administration of insulin.

\subsection{Transdermal insulin delivery}

Although in the ClinicalTrials.gov database no transdermal formulations have been reported in the past decade, recent searches of reviews show a possible transdermal formulation that is in the later stages of clinical trials. It is the non-invasive U-Strip (Ultrasonic Strip) transdermal patch designed by Transdermal Specialities, which can be used by both type 1 and type 2 diabetics [74]. This system is a two component system, consisting of the insulin patch, which uses an absorbent pad containing up to 150 units of insulin, that is attached to the second component the U-Strip controller, which is a transducer device that generates a unique alternating ultrasonic transmission [75]. The U-Strip system utilises two types of ultrasonic waveforms, initially sawtooth waveforms are used to expand the pore diameter from roughly $50 \mu \mathrm{m}$ to $110 \mu \mathrm{m}$ to facilitate the penetration of large molecules, such as insulin, then square waveforms are emitted to actively force insulin through the enlarged pores into the dermis and into the blood circulation. The U-Strip device is portable, battery operated, and designed to release insulin, specifically insulin lispro, only when the ultrasound is activated. It is also programmable, can be worn on either one of the arms or on the belt, and has a touch screen to enable patients to control both dosage levels and frequency. Additionally, the device can store data, which is transferable via the internet and hence can be a useful record for the management of patient's treatment and compliance by their healthcare team. The information has been provided by Bruce $\mathrm{K}$ Redding, Jr, who is the president of Transdermal Specialties. Considering that 12 human clinical trials have been completed successfully and an additional 500 patient trial is underway the technology looks promising and it will be interesting to see further developments in the future. 


\begin{tabular}{|c|c|c|c|c|c|c|}
\hline \multicolumn{7}{|c|}{ Pulmonary Insulin Delivery } \\
\hline $\begin{array}{l}\text { Product } \\
\text { Name }\end{array}$ & Company & Technology & $\begin{array}{l}\text { Year Trial } \\
\text { Started }\end{array}$ & Phase & NCT Number & $\begin{array}{l}\text { Reference } \\
\text { (s) }\end{array}$ \\
\hline \multirow{2}{*}{$\begin{array}{l}\text { Dance- } \\
501\end{array}$} & \multirow[t]{2}{*}{ Dance Biopharm } & \multirow[b]{2}{*}{$\begin{array}{l}\text { Inhaled insulin } \\
\text { administered using the } \\
\text { Adagio-01 inhaler } \\
\text { device (also known as } \\
\text { dance-501). The device } \\
\text { uses a vibrating mesh } \\
\text { micropump technology } \\
\text { developed by Aerogen. }\end{array}$} & 2013 & $1 \& 2$ & NCT02713841 & \multirow[t]{2}{*}[50]{} \\
\hline & & & 2016 & $1 \& 2$ & NCT02716610 & \\
\hline \multirow[t]{17}{*}{ Afrezza $^{\circledR}$} & \multirow{17}{*}{$\begin{array}{l}\text { Mannkind } \\
\text { Corporation \& } \\
\text { Sanofi }\end{array}$} & \multirow{17}{*}{$\begin{array}{l}\text { Technosphere }{ }^{\circledR} \text { Insulin } \\
\text { SAR439065 Afrezza }{ }^{\circledR} . \\
\text { Technosphere }{ }^{\circledR} \\
\text { particles are formed } \\
\text { using the carrier } \\
\text { fumaryl } \\
\text { diketopiperazine } \\
\text { (FDKP). Insulin is } \\
\text { adsorbed onto the } \\
\text { particles (around } 2 \mu \mathrm{m} \\
\text { in size) forming } \\
\text { Technosphere }{ }^{\circledR} \text { insulin. }\end{array}$} & \multirow[t]{5}{*}{2008} & 1 & NCT00673621 & \multirow[t]{17}{*}{ [5] } \\
\hline & & & & 2 & NCT00662857 & \\
\hline & & & & 1 & NCT00674050 & \\
\hline & & & & 2 & NCT00747006 & \\
\hline & & & & 3 & NCT00700622 & \\
\hline & & & 2009 & 3 & NCT00642616 & \\
\hline & & & 2010 & 3 & NCT01196104 & \\
\hline & & & \multirow[t]{2}{*}{2011} & 3 & NCT01451398 & \\
\hline & & & & 3 & NCT01445951 & \\
\hline & & & 2012 & 1 & NCT01544881 & \\
\hline & & & \multirow[t]{3}{*}{2015} & 1 & NCT02485327 & \\
\hline & & & & 1 & NCT02470637 & \\
\hline & & & & 2 & NCT02527265 & \\
\hline & & & \multirow[t]{4}{*}{2017} & $1 \& 2$ & NCT03234491 & \\
\hline & & & & 3 & NCT03324776 & \\
\hline & & & & 4 & NCT03143816 & \\
\hline & & & & 4 & NCT03313960 & \\
\hline \multicolumn{7}{|c|}{ Buccal Insulin Delivery } \\
\hline $\begin{array}{l}\text { Product } \\
\text { Name }\end{array}$ & Company & Technology & $\begin{array}{l}\text { Year Trial } \\
\text { Started }\end{array}$ & Phase & NCT Number & $\begin{array}{l}\text { Reference } \\
\text { (s) }\end{array}$ \\
\hline $\begin{array}{l}\text { Oral- } \\
\text { lyn }\end{array}$ & $\begin{array}{l}\text { Generex } \\
\text { Biotechnology } \\
\text { Corp. }\end{array}$ & $\begin{array}{l}\text { Formulation contains } \\
\text { surfactants as } \\
\text { absorption enhancers } \\
\text { by forming insulin } \\
\text { containing micelles. } \\
\text { Generex Oral-lyn }{ }^{\mathrm{TM}} \\
\text { delivers insulin via a }\end{array}$ & 2008 & 3 & NCT00668850 & {$[45,47,48]$} \\
\hline
\end{tabular}




\begin{tabular}{|c|c|c|c|c|c|c|}
\hline & & $\begin{array}{l}\text { device known as } \\
\text { RapidMist }^{\mathrm{TM}} \text {. }\end{array}$ & & & & \\
\hline \multicolumn{7}{|c|}{ Oral Insulin Delivery } \\
\hline $\begin{array}{l}\text { Product } \\
\text { Name }\end{array}$ & Company & Technology & $\begin{array}{l}\text { Year Trial } \\
\text { Started }\end{array}$ & Phase & NCT Number & $\begin{array}{l}\text { Reference } \\
\text { (s) }\end{array}$ \\
\hline \multirow[t]{6}{*}{ GIPET $^{\circledR}$ I } & \multirow[t]{6}{*}{ Novo Nordisk } & \multirow{6}{*}{$\begin{array}{l}\text { GIPET }^{\circledR} \text { I tablet } \\
\text { preparation consists of } \\
\text { micelles formed with } \\
\text { the aid of patented } \\
\text { absorption enhancers. }\end{array}$} & 2013 & 1 & NCT01809184 & \multirow[t]{6}{*}{ [57] } \\
\hline & & & \multirow[t]{2}{*}{2013} & 1 & NCT01796366 & \\
\hline & & & & 1 & NCT01931137 & \\
\hline & & & 2014 & 1 & NCT02304627 & \\
\hline & & & \multirow[t]{2}{*}{2015} & 2 & NCT02470039 & \\
\hline & & & & 1 & NCT02479022 & \\
\hline \multirow{6}{*}{$\begin{array}{l}\text { ORMD- } \\
0801\end{array}$} & \multirow{6}{*}{$\begin{array}{l}\text { Oramed, Ltd. \& } \\
\text { Integrium }\end{array}$} & \multirow{6}{*}{$\begin{array}{l}\text { ORMD-0801 consists of } \\
\text { an enteric coated } \\
\text { capsule } \\
\text { encompasses insulin } \\
\text { along with protease } \\
\text { inhibitors } \\
\text { absorption enhancers } \\
\text { that aid delivery in the } \\
\text { small intestine. }\end{array}$} & 2008 & 2 & NCT00867594 & \multirow[t]{6}{*}{ [59] } \\
\hline & & & 2013 & 2 & NCT01889667 & \\
\hline & & & 2014 & 2 & NCT02094534 & \\
\hline & & & \multirow[t]{2}{*}{2015} & 2 & NCT02535715 & \\
\hline & & & & 2 & NCT02496000 & \\
\hline & & & 2016 & 2 & NCT02954601 & \\
\hline \multirow[t]{3}{*}{$\begin{array}{l}\text { Oshadi } \\
\text { Oral } \\
\text { Insulin }\end{array}$} & \multirow[t]{3}{*}{$\begin{array}{l}\text { Oshadi Drug } \\
\text { Administration }\end{array}$} & \begin{tabular}{|lr}
\multicolumn{3}{l}{ Oshadi carrier contains } \\
a mixture of \\
pharmacologically \\
inert rilica \\
nanoparticles with a \\
hydrophobic surface \\
and a branched \\
polysaccharide. Insulin \\
is suspended, \\
embedded or \\
dispersed in an oil or \\
mixture of oils
\end{tabular} & 2010 & 1 & NCT01120912 & \multirow[t]{3}{*}{ [64] } \\
\hline & & \multirow{2}{*}{$\begin{array}{l}\text { Oshadi Icp (insulin, } \\
\text { proinsulin and C- } \\
\text { peptide in Oshadi } \\
\text { carrier) }\end{array}$} & \multirow[t]{2}{*}{2013} & $1 \& 2$ & NCT01772251 & \\
\hline & & & & 2 & NCT01973920 & \\
\hline $\begin{array}{l}\text { HDV } \\
\text { Insulin }\end{array}$ & $\begin{array}{l}\text { Diasome } \\
\text { Pharmaceuticals } \\
\text { \& Integrium }\end{array}$ & $\begin{array}{l}\text { In the HDV (hepatocyte } \\
\text { directed vesicle) insulin } \\
\text { gel capsule the insulin } \\
\text { is bound to HDV. The } \\
\text { HDV vesicle is less than }\end{array}$ & 2008 & $2 \& 3$ & NCT00814294 & {$[61]$} \\
\hline
\end{tabular}




\begin{tabular}{|c|c|c|c|c|c|c|}
\hline & & $\begin{array}{l}150 \mathrm{~nm} \text { in diameter } \\
\text { and the phospholipid } \\
\text { bilayer has specific } \\
\text { hepatocyte-targeting } \\
\text { molecule (HTM), which } \\
\text { in the latest } \\
\text { preparation is biotin- } \\
\text { phosphatidylethanola } \\
\text { mine (biotin-PE). }\end{array}$ & 2016 & 2 & NCT02794155 & \\
\hline IN-105 & Biocon Limited & $\begin{array}{l}\text { The tablet formulation } \\
\text { IN-105 oral insulin } \\
\text { (now known as } \\
\text { Tregopil) is a modified } \\
\text { form of human insulin } \\
\text { where the free amino } \\
\text { acid group on the Lys- } \\
\beta 29 \text { residue has been } \\
\text { covalently bonded via a } \\
\text { non-hydrolysable } \\
\text { amide bond to a small } \\
\text { polyethylene glycol } \\
\text { (PEG) molecule. This } \\
\text { modification offers } \\
\text { better stability and } \\
\text { reduced degradation in } \\
\text { the presence of } \\
\text { enzymes in the GIT. }\end{array}$ & 2010 & 1 & NCT01035801 & {$[66,67]$} \\
\hline \multirow[t]{2}{*}{ ORA2 } & \multirow{2}{*}{$\begin{array}{l}\text { Bows } \\
\text { Pharmaceuticals } \\
\text { AG }\end{array}$} & \multirow{2}{*}{$\begin{array}{l}\text { Insulin in dextran } \\
\text { matrix capsule. }\end{array}$} & 2009 & $1 \& 2$ & NCT00990444 & \\
\hline & & & 2010 & 1 & NCT01114750 & \\
\hline \multicolumn{7}{|c|}{ Nasal Insulin Delivery } \\
\hline $\begin{array}{l}\text { Product } \\
\text { Name }\end{array}$ & Company & Technology & $\begin{array}{l}\text { Year Trial } \\
\text { Started }\end{array}$ & Phase & NCT Number & $\begin{array}{l}\text { Reference } \\
\text { (s) }\end{array}$ \\
\hline \multirow[t]{2}{*}{ Nasulin $^{\mathrm{TM}}$} & \multirow{2}{*}{$\begin{array}{l}\text { CPEX } \\
\text { Pharmaceuticals } \\
\text { Inc. }\end{array}$} & \multirow[b]{2}{*}{$\begin{array}{l}\text { The intranasal insulin } \\
\text { spray contains } \\
\text { cyclopentadecalactone } \\
\text { (CPE-215), which is the } \\
\text { main excipient in the } \\
\text { permeation } \\
\text { enhancement } \\
\text { technology of CPEX. }\end{array}$} & \multirow[t]{2}{*}{2009} & 2 & NCT00850161 & \multirow[t]{2}{*}[72,73]{} \\
\hline & & & & 2 & NCT00850096 & \\
\hline
\end{tabular}

\section{Overview of recent therapies}

Afrezza ${ }^{\circledR}$ is a newer, non-invasive, rapid-acting inhaled human insulin product, produced by MannKind Corporation, that is currently in clinical use in the USA [49]. It was approved, for adults with type 1 
and type 2 diabetes mellitus, by FDA in June 2014 but in UK and Europe it is currently still in phase 3 clinical trials $[5,76]$. The safety and efficacy of Afrezza ${ }^{\circledR}$ was assessed in 3017 patients before the formulation was approved by the FDA. The insulin for this portable inhaler product is a dry powder formulation, which is contained in single use cartridges comprising of 4,8 or 12 unit doses of insulin [77]. Upon inhalation, which is powered by the patient's force of inhalation, the Technosphere ${ }^{\circledR}$ insulin particles are aerosolized and delivered to the lung alveoli [78]. Technosphere ${ }^{\circledR}$ particles are formed using the carrier fumaryl diketopiperazine (FDKP), which under acidic conditions, self-assembles into microparticles, and this allows for the recombinant human insulin to adsorb onto the particles (around $2 \mu \mathrm{m}$ in size) and form Technosphere ${ }^{\circledR}$ insulin [5,79]. The formed microparticles have median diameters of around 2-2.5 micrometers, which enables excellent particle size for delivery of molecules to the deep lungs. The alveolar fluid of the deep lungs provides an ideal environment for the rapid dissolution of technosphere ${ }^{\circledR}$ insulin; due to the high solubility of the FDPK molecule, in water at neutral or basic $\mathrm{pH}$. After absorption across the alveoli into the bloodstream, the FDKP molecule remains unchanged and is excreted by the kidneys [78]. Although Afrezza ${ }^{\circledR}$ can be substituted for mealtime insulin, patients will still need to inject their long-acting basal insulin [80]. The pharmacokinetic and pharmacodynamic properties of Afrezza was assessed in 30 patients with T1DM in a recent randomized, controlled 6-way, crossover dose response study [79]. The study looked at the comparison of inhaling 4, 12 or 48 units of insulin using Afrezza compared to subcutaneous administration of 8,30 or 90 units of insulin lispro. For inhaled insulin the onset of action was around 12 minutes, the peak effect occurred between 35-55 minutes and baseline levels were reached around 90 to 270 minutes. The peak action for insulin lispro, on the other hand, was around 90 to 180 minutes with baseline levels reaching between 360 to 660 minutes. Nonetheless, the baseline levels for both Afrezza and insulin lispro were noted to have reached in a dose-dependent manner. Based on the data in this study for insulin lispro, as well as the results for Humalog ${ }^{\circledR}$ published on the electronic medicines compendium and shown in Table 3 , it can be seen that in comparison to subcutaneous administration the inhaled Afrezza is both faster in onset and has a shorter duration of action [81]. As shown in Figure 3, there are many advantages for delivering insulin via the pulmonary route but there are also quite a few disadvantages and some of these are experienced with Afrezza ${ }^{\circledR}$ as it is not suitable for patients with chronic lung disease, due to risk of acute bronchospasm, and not recommended for smokers or those who have recently quit smoking [49].

Table 3. Comparison of the pharmacokinetic and pharmacodynamic profile of a current subcutaneous rapid acting insulin and the newer buccal and inhaled insulin formulations.

\begin{tabular}{|c|c|c|c|c|c|c|}
\hline Product & $\mid \begin{array}{ll}\text { Type } & \text { of } \\
\text { insulin }\end{array}$ & $\begin{array}{l}\text { Route/method } \\
\text { of } \\
\text { administration }\end{array}$ & $\begin{array}{l}\text { Onset of } \\
\text { action } \\
\text { (minutes) }\end{array}$ & $\begin{array}{l}\text { Peak } \\
\text { action } \\
\text { (minutes) }\end{array}$ & $\begin{array}{l}\text { Time for } \\
\text { effect to } \\
\text { return to } \\
\text { baseline } \\
\text { (minutes) }\end{array}$ & Reference(s) \\
\hline Humalog $^{\circledR}$ & $\mid \begin{array}{l}\text { Rapid acting } \\
\text { insulin lispro }\end{array}$ & $\begin{array}{l}\text { Injected in the } \\
\text { subcutaneous } \\
\text { tissue }\end{array}$ & $\sim 15$ & $\sim 90$ & $\begin{array}{l}\sim 120 \text { to } \\
300\end{array}$ & [81] \\
\hline Oral-lyn ${ }^{\mathrm{TM}}$ & $\mid \begin{array}{l}\text { Regular } \\
\text { human insulin }\end{array}$ & $\begin{array}{l}\text { Sprayed on the } \\
\text { buccal } \\
\text { membrane }\end{array}$ & $\sim 32$ & $\sim 44$ & $\sim 85$ & [86] \\
\hline Afrezza $^{\circledR}$ & $\begin{array}{l}\text { Recombinant } \\
\text { human insulin }\end{array}$ & $\begin{array}{l}\text { Inhaled for } \\
\text { absorption in the } \\
\text { deep lungs }\end{array}$ & $\sim 12$ & $\sim 35$ to 55 & $\begin{array}{l}\sim 90 \text { to } \\
270\end{array}$ & [79] \\
\hline
\end{tabular}

Another product of interest is the Generex Oral-lyn ${ }^{\mathrm{TM}}$ (or Oralin ${ }^{\mathrm{TM}}$ ) spray, produced by the Canadian company Generex Biotechnology, for use as prandial insulin in T1DM and T2DM. It has been approved for clinical use in Ecuador and Lebanon but in Canada, US and Europe the product is still in phase 3 
clinical trials $[6,43,82]$. Oral-lyn ${ }^{\text {TM }}$ has been approved by the FDA for treatment of patients under the Investigational New Drug (IND) program, which allows the drug to be accessible to patients with serious or life-threatening Type 1 or Type 2 diabetes mellitus who are not eligible for the phase 3 clinical trials and there are no other alternative satisfactory treatment [82]. The insulin within the preparation is stable at room temperature for at least six months and is formulated using a combination of absorption enhancers and small amounts of excipients classified by the FDA as generally recognised as safe (GRAS) [43,83]. In the formulation surfactants, which form insulin containing micelles, are used as absorption enhancers and this appears to be a critical component of the Generex drug delivery system. Generex Oral-lyn ${ }^{\mathrm{TM}}$ delivers insulin via a device known as RapidMist $^{\mathrm{TM}}$, which in appearance is similar to metered dose systems used in asthma and chronic obstructive pulmonary disease treatment [84]. It delivers regular human insulin to the buccal mucosa; the insulin containing micelles are larger than $7 \mu \mathrm{m}$ and hence are too big to reach alveoli and are impacted in the buccal cavity. Each canister contains 400 units of insulin and while 1 puff holds 10 units of insulin only $10 \%$ of the drug is absorbed; hence with each spray 1 unit of insulin is delivered to the blood circulation $[43,84]$. In practice many patients require 10 units or more of insulin with each meal, some considerably more, and hence using the device to administer 10 or more puffs each time can be become inconvenient and may not be feasible for the long-term. In a comparative study of insulin levels in type 1 diabetic patients, where Oral-lyn ${ }^{\mathrm{TM}}$ insulin was compared to sc injections of insulin or placebo, it was observed that with Oral-lyn ${ }^{\mathrm{TM}}$ the entry of insulin into the blood circulation was much faster compared to sc injections and insulin levels could be detected within 10 minutes of administration [85]. Additionally, Oral-lyn ${ }^{\mathrm{TM}}$ insulin reached peak insulin levels at 30 minutes whereas sc injections were much slower in comparison. At 150 minutes Oral-lyn ${ }^{\mathrm{TM}}$ insulin had almost reached baseline level whereas sc injections of insulin were still around peak levels. This small study, together with another study (data shown in Table 3), demonstrates that buccal insulin could possibly be more reflective of normal insulin response to meal intake in non-diabetic individuals compared to sc injection, taking less time to reach peak activity and having a shorter duration of action $[85,86]$. Although there are some advantages of the Oral-lyn ${ }^{\mathrm{TM}}$ device and formulation, the low bioavailability of the formulation can be a major drawback for the product obtaining approval worldwide.

\section{Conclusion and future directions}

Insulin forms a major part in the diabetes treatment plan. In the future the ideal and most convenient situation for diabetic patients would be to take insulin orally in the form of a tablet or capsule but based on the challenges of delivering proteins via the GI tract, the success of such a concept needs further development. On a positive note, even though many have failed, most trials in relation to insulin are related to oral delivery products. Hence there is some possibility that an orally delivered insulin formulation will be approved by regulatory authorities (e.g. MHRA and FDA) in the next decade or two. The challenge is finding a formulation that is clinically effective, safe and convenient for longterm daily administration. But if this is achieved, it will likely be for a long-acting basal insulin formulation, in order to minimise use of excipients, such as absorption enhancers or enzyme inhibitors, and also to overcome challenges, such as the fed and fasted state, and to avoid the critical timing associated with lowering meal time glucose levels in the systemic circulation. One of the main products that appear promising is the oral HDV insulin gel capsule; as this formulation allows for a low dose of insulin to be used and as such it has the theoretical benefit of having a lower risk of hypoglycaemia compared to the other oral preparations that contain much higher doses of insulin.

Two other promising non-invasive products include the Dance-501 hand-held insulin inhaler device and the U-strip transdermal insulin patch system. The Dance-501 device has overcome many of the weaknesses faced by the Exubera and has several advantages in terms of the design: as it is small, discrete and more patient friendly for use outside the home. But this new inhaled insulin delivery system has the drawback of requiring administration of 10 times more insulin in order to obtain the 
equivalent amount of insulin from subcutaneous administration of insulin. If the bioavailability can be improved the Dance-501 device can have a promising future ahead. The U-Strip system is another innovative technology. It is unique as the transdermal delivery of insulin is enhanced by combining two types of ultrasonic waveforms. Although currently a relatively bulky controller is required, it would be advantageous if this can be reduced in size, but overall the technology appears promising and the outcome of the current clinical trials will be of interest once revealed. Afrezza ${ }^{\circledR}$ has been FDA approved; nonetheless still faces a number of challenges including obtaining approval in Europe. Generex Oral-lyn ${ }^{\mathrm{TM}}$ spray also requires approval in Europe, the USA and many other countries worldwide. Once these two products become approved and in common use in Europe and the USA then will non-invasive insulin administration become a reality and allow for other newer formulations to have a better opportunity of success and approval. There are many challenges to overcome but achievement of a formulation, that can replace subcutaneous injections, would not only be a great accomplishment scientifically, in terms of delivering a protein safely for chronic use non-invasively, but also a major contribution to easing the lives of millions of patients and reducing healthcare costs worldwide.

\section{References}

[1] World Health Organization. Global report on diabetes. France: 2016.

[2] Wild S, Roglic G, Green A, Sicree R, King H. Global Prevalence of Diabetes. Diabetes Care 2004;27:1047-53.

[3] Whiting DR, Guariguata L, Weil C, Shaw J. IDF Diabetes Atlas: Global estimates of the prevalence of diabetes for 2011 and 2030. Diabetes Res Clin Pract 2011;94:311-21. doi:10.1016/J.DIABRES.2011.10.029.

[4] Cho NH, Shaw JE, Karuranga S, Huang Y, da Rocha Fernandes JD, Ohlrogge AW, et al. IDF Diabetes Atlas: Global estimates of diabetes prevalence for 2017 and projections for 2045. Diabetes Res Clin Pract 2018;138:271-81. doi:10.1016/j.diabres.2018.02.023.

[5] Klonoff DC. Afrezza Inhaled Insulin. J Diabetes Sci Technol 2014;8:1071-3.

[6] Morales JO, Brayden JD. Buccal delivery of small molecules and biologics: of mucoadhesive polymers, films, and nanoparticles. Curr Opin Pharmacol 2017;36:22-8.

[7] U.S. National Library of Medicine. Insulin Interventional Studies Diabetes 2017. https://clinicaltrials.gov/ (accessed December 23, 2017).

[8] Ashcroft F, Ashcroft S. Insulin synthesis. Insul. Mol. Biol. to Pathol., USA: Oxford University Press; 1992, p. 64-87.

[9] World Health Organization. Definition, Diagnosis and Classification of Diabetes Mellitus and its Complications. Geneva: 1999.

[10] The Diabetes Control and Complications Trial Research Group. The effect of intensive treatment of diabetes on the development and progression of long-term complications in insulin-dependent diabetes mellitus. N Engl J Med 1993;329:977-86.

[11] Research CT, The Diabetes Control and Complications Trial Research Group. Effect of intensive diabetes treatment on the development and progression of long-term complications in adolescents with insulin-dependent diabetes mellitus: Diabetes Control and Complications Trial. J Pediatr 1994;125:177-88. 
[12] Diabetes Control and Complications Trial/Epidemiology of Diabetes Interventions and Complications Research Group, Lachin JM, Genuth S, Cleary P, Davis MD, Nathan DM. Retinopathy and nephropathy in patients with type 1 diabetes four years after a trial of intensive therapy. N Engl J Med 2000;342:381-9.

[13] Banting FB, Best CH. The internal secretion of the pancreas. J Lab Clin Med 1922;7:251-66.

[14] Madison JH. Manufacturing Pharmaceuticals: Eli Lilly and Company, 1876-1948. Bus Econ Hist 1989;18:72-8.

[15] Gatchair SD, Bortagaray I, Brito L, Brouwer R. Uneven publics:life, death, and recombinant insulin. Innov. Inequal. Emerg. Technol. an unequal world, Cheltenham, Northampton: Edward Elgar Publishing; 2014, p. 67-76.

[16] Howey DC, Bowsher RR, Brunelle RL, Woodworth JR. Lys(B28), Pro(B29)]-human insulin. A rapidly absorbed analogue of human insulin. Diabetes 1994;43:396-402.

[17] Crommelin DJA. Insulin. In: Sindelar RD, Meibohm B, editors. Pharm. Biotechnol. Fundam. Appl. 3rd ed., Hoboken: Taylor and Francis; 2007, p. 265-78.

[18] Heinemann L. The failure of exubera: are we beating a dead horse? J Diabetes Sci Technol 2008;2:518-29.

[19] FDA. FDA News Release: FDA approves two new drug treatments for diabetes mellitus 2015. https://www.fda.gov/NewsEvents/Newsroom/PressAnnouncements/ucm464321.htm (accessed February 20, 2017).

[20] European Medicines Agency. EMEA-000456-PIP01-08-M02 2014. http://www.ema.europa.eu/ema//index.jsp?curl=pages/medicines/pips/EMEA-000456PIP01-08-M02/pip_000397.jsp (accessed March 20, 2017).

[21] European Medicines Agency. Find medicine: Fiasp insulin aspart 2017. http://www.ema.europa.eu/ema/index.jsp?curl=pages/medicines/human/medicines/004046 /human_med_002063.jsp (accessed March 20, 2017).

[22] Heise T, Hövelmann U, Brøndsted L, Adrian CL, Nosek L, Haahr H. Faster-acting insulin aspart: earlier onset of appearance and greater early pharmacokinetic and pharmacodynamic effects than insulin aspart. Diabetes, Obes Metab 2015;17:682-8.

[23] Fu Z, Gilbert ER, Liu D. Regulation of insulin synthesis and secretion and pancreatic Beta-cell dysfunction in diabetes. Curr Diabetes Rev 2013;9:25-53.

[24] Matteucci E, Giampietro O, Covolan V, Giustarini D, Fanti P, Rossi R. Insulin administration: present strategies and future directions for a noninvasive (possibly more physiological) delivery. Drug Des Devel Ther 2015;9:3109-18.

[25] Guo H, Xiong Y, Witkowski P, Cui J, Wang LJ, Sun J, et al. Inefficient translocation of preproinsulin contributes to pancreatic beta cell failure and late-onset diabetes. J Biol Chem 2014;289:16290-302.

[26] Poitout V, Hagman D, Stein R, Artner I, Robertson RP, Harmon JS. Regulation of the insulin gene by glucose and fatty acids. J Nutr 2006;136:873-6.

[27] Wolin SL, Walter P. Discrete nascent chain lengths are required for the insertion of presecretory proteins into microsomal membranes. J Cell Biol 1993;121:1211-9.

[28] Okun MM, Shields D. Translocation of preproinsulin across the endoplasmic reticulum membrane. The relationship between nascent polypeptide size and extent of signal 
recognition particle-mediated inhibition of protein synthesis. J Biol Chem 1992;267:1147682.

[29] Patzelt C, Labrecque AD, Duguid JR, Carroll RJ, Keim PS, Heinrikson RL, et al. Detection and kinetic behavior of preproinsulin in pancreatic islets. Proc Natl Acad Sci U S A 1978;75:12604.

[30] Chan SJ, Keim P, Steiner DF. Cell-free synthesis of rat preproinsulins: characterization and partial amino acid sequence determination. Proc Natl Acad Sci U S A 1976;73:1964-8.

[31] Beckers CJ, Balch WE. Calcium and GTP: essential components in vesicular trafficking between the endoplasmic reticulum and Golgi apparatus. J Cell Biol 1989;108:1245-56.

[32] Dunn MF. Zinc-ligand interactions modulate assembly and stability of the insulin hexamer-a review. Biometals 2005;18:295-303.

[33] Galloway JA, Chance RE. Improving insulin therapy: achievements and challenges. Horm Metab Res 1994;26:591-8.

[34] Hyllested-Winge J, Jensen KH, Rex J. A Review of 25 Years' Experience with the NovoPen ${ }^{\circledR}$ Family of Insulin Pens in the Management of Diabetes Mellitus. Clin Drug Investig 2010;30:643-74.

[35] Joint Formulary Committee. Chapter 6: Endocrine System. Br. Natl. Formul. 72, London: BMJ Group \& Pharmaceutical Press; 2016, p. 640-6.

[36] Anhalt H, Bohannon NJ V. Insulin patch pumps: their development and future in closed-loop systems. Diabetes Technol Ther 2010;12:51-8.

[37] Zisser HC. The OmniPod Insulin Management System: the latest innovation in insulin pump therapy. Diabetes Ther 2010;1:10-24.

[38] Winter A, Lintner M, Knezevich E. V-Go Insulin Delivery System Versus Multiple Daily Insulin Injections for Patients With Uncontrolled Type 2 Diabetes Mellitus. J Diabetes Sci Technol 2015;9:1111-6.

[39] Gilbert M, Pratley RE. V-Go ${ }^{\mathrm{TM}}$-A Novel Device for Delivering Basal-Bolus Insulin Therapy to Patients with Type 2 Diabetes Mellitus. 2007.

[40] Harris D, Robinson JR. Drug Delivery via the Mucous Membranes of the Oral Cavity. J Pharm Sci 1992;81:1-10.

[41] Shojaei AH. Buccal mucosa as a route for systemic drug delivery: a review. J Pharm Sci 1998;1:15-30.

[42] Tanner T, Marks R. Delivering drugs by the transdermal route: review and comment. Ski Res Technol 2008;14:249-60.

[43] Heinemann L, Jacques Y. Oral insulin and buccal insulin: a critical reappraisal. J Diabetes Sci Technol 2009;3:568-84.

[44] Henkin RI. Inhaled insulin-Intrapulmonary, intranasal, and other routes of administration: Mechanisms of action. Nutrition 2010;26:33-9.

[45] Hultstrom M, Roxhed N, Nordquist L. Intradermal insulin delivery: a promising future for diabetes management. J Diabetes Sci Technol 2014;8:453-7.

[46] Cavaiola TS, Edelman S. Inhaled insulin: a breath of fresh air? A review of inhaled insulin. Clin Ther 2014;36:1275-89. 
[47] Silva BMA, Borges AF, Silva C, Coelho JFJ, Simões S. Mucoadhesive oral films: The potential for unmet needs. Int J Pharm 2015;494:537-51.

[48] Rathbone MJ, Pather I, Şenel S. Overview of Oral Mucosal Delivery. Oral Mucosal Drug Deliv. Ther., Boston: Springer; 2015, p. 17-29.

[49] FDA. AFREZZA ${ }^{\circledast}$ (insulin human) Inhalation Powder 2014. https://www.accessdata.fda.gov/drugsatfda_docs/nda/2014/0224720rig1s000TOC.cfm (accessed January 21, 2018).

[50] Fink JB, Molloy L, Patton JS, Galindo-Filho VC, de Melo Barcelar J, Alcoforado L, et al. Good Things in Small Packages: an Innovative Delivery Approach for Inhaled Insulin. Pharm Res 2017;34:2568-78.

[51] Kim D, Mudaliar S, Chinnapongse S, Chu N, Boies SM, Davis T, et al. Dose-response relationships of inhaled insulin delivered via the Aerodose insulin inhaler and subcutaneously injected insulin in patients with type 2 diabetes. Diabetes Care 2003;26:2842-7.

[52] Midatech Pharma. News Release: Initiation of Phase Ila study of insulin delivery via buccal strip for type 1 diabetes 2015. http://www.midatechpharma.com/news/49/143/Initiation-ofPhase-Ila-study-of-insulin-delivery-via-buccal-strip-for-type-1-diabetes.html (accessed March 20, 2017).

[53] Morales JO, Fathe KR, Brunaugh A, Ferrati S, Li S, Montenegro-Nicolini M, et al. Challenges and Future Prospects for the Delivery of Biologics: Oral Mucosal, Pulmonary, and Transdermal Routes. AAPS J 2017;19:652-68.

[54] Midatech Pharma. Midatech's primary platform technology is based on carbohydrate-coated gold nanoparticle (GNP) drug conjugates. 2017. http://www.midatechpharma.com/gnptechnology (accessed March 20, 2017).

[55] Midatech Pharma. News Release: Midatech Pharma announces clinical pipeline update 2016. http://www.midatechpharma.com/news/69/143/Midatech-Pharma-announces-clinicalpipeline-update.html (accessed March 21, 2017).

[56] Fonte P, Araujo F, Reis S, Sarmento B. Oral insulin delivery: how far are we? J Diabetes Sci Technol 2013;7:520-31.

[57] Novo Nordisk. Company announcement: Financial report for the period 1 January 2015 to 30 June 2015. 2015.

[58] Oramed Pharmaceuticals. Technology 2016. http://www.oramed.com/technology/ (accessed February 5, 2017).

[59] Eldor R, Arbit E, Corcos A, Kidron M. Glucose-Reducing Effect of the ORMD-0801 Oral Insulin Preparation in Patients with Uncontrolled Type 1 Diabetes: A Pilot Study. PLoS One 2013;8:e59524.

[60] Geho WB, Geho HC, Lau JR, Gana TJ. Hepatic-directed vesicle insulin: a review of formulation development and preclinical evaluation. J Diabetes Sci Technol 2009;3:1451-9.

[61] Diasome Pharmaceuticals. Pipeline 2016. http://diasomepharmaceuticals.com/pipeline/ (accessed February 11, 2017).

[62] Luzio SD, Dunseath G, Lockett A, Broke-Smith TP, New RR, Owens DR. The glucose lowering effect of an oral insulin (Capsulin) during an isoglycaemic clamp study in persons with type 2 diabetes. Diabetes, Obes Metab 2010;12:82-7. 
[63] Gribova O, Vol A. Methods and compositions for oral administration of insulin. 20100278922, 2010.

[64] Zijlstra E, Heinemann L, Plum-Mörschel L. Oral Insulin Reloaded: A Structured Approach. J Diabetes Sci Technol 2014;8:458-65.

[65] Biocon. Active Discovery Programs 2016. http://www.biocon.com/biocon_research_discovery.asp (accessed February 19, 2017).

[66] Khedkar A, lyer H, Anand A, Verma M, Krishnamurthy S, Savale S, et al. A dose range finding study of novel oral insulin (IN-105) under fed conditions in type 2 diabetes mellitus subjects. Diabetes, Obes Metab 2010;12:659-64.

[67] Diabetology. Capsulin 2017. http://www.diabetology.co.uk/projects/capsulin/ (accessed March 31, 2018).

[68] Diabetology. Axcess Oral Delivery System 2017. http://www.diabetology.co.uk/technology/ (accessed March 31, 2018).

[69] Muheem A, Shakeel F, Jahangir MA, Anwar M, Mallick N, Jain GK, et al. A review on the strategies for oral delivery of proteins and peptides and their clinical perspectives. Saudi Pharm J 2016;24:413-28.

[70] Swenson SE, Curatolo WJ. (C) Means to enhance penetration: (2) Intestinal permeability enhancement for proteins, peptides and other polar drugs: mechanisms and potential toxicity. Adv Drug Deliv Rev 1992;8:39-92.

[71] CPEX Pharmaceuticals. Permeation Enhancement Technology 2011. http://www.cpexpharmaceuticals.com/permeation-technology.html (accessed February 19, 2017).

[72] Stote R, Miller M, Marbury T, Shi L, Strange P. Enhanced absorption of Nasulin ${ }^{\top \mathrm{M}}$, an ultrarapid-acting intranasal insulin formulation, using single nostril administration in normal subjects. J Diabetes Sci Technol 2011;5:113-9.

[73] Leary AC, Dowling M, Cussen K, O'Brien J, Stote RM. Pharmacokinetics and pharmacodynamics of intranasal insulin spray ( Nasulin $^{T \mathrm{M}}$ ) administered to healthy male volunteers: influence of the nasal cycle. J Diabetes Sci Technol 2008;2:1054-60.

[74] Shahani S, Shahani L. Use of insulin in diabetes: a century of treatment. Hong Kong Med J = Xianggang Yi Xue Za Zhi 2015;21:553-9.

[75] Redding BK. Transdermal Specialties: Designing an ultrasound enabled patch for Insulin. Frederick Furness Publ Ltd 2014:22-6.

[76] Specialist Pharmacy Service. Insulin Inhaled 2017. https://www.sps.nhs.uk/medicines/insulininhaled/ (accessed October 15, 2018).

[77] Goldberg T, Wong E. Afrezza (Insulin Human) Inhalation Powder: A New Inhaled Insulin for the Management Of Type-1 or Type-2 Diabetes Mellitus. P T 2015;40:735-41.

[78] Kim ES, Plosker GL. AFREZZA ${ }^{\circledR}$ (insulin human) Inhalation Powder: A Review in Diabetes Mellitus. Drugs 2015;75:1679-86.

[79] Heinemann L, Parkin CG. Rethinking the Viability and Utility of Inhaled Insulin in Clinical Practice. J Diabetes Res 2018;2018:1-9. doi:10.1155/2018/4568903.

[80] Fleming LW, Fleming JW, Davis CS. Afrezza: An inhaled approach to insulin delivery. J Am 
Assoc Nurse Pract 2015;27:597-601.

[81] Eli Lilly and Company Limited. Humalog 100 units/ml KwikPen, solution for injection in a prefilled pen 2018. https://www.medicines.org.uk/emc/product/8545/smpc (accessed October $16,2018)$.

[82] Specialist Pharmacy Service. Insulin Buccal 2018. https://www.sps.nhs.uk/medicines/insulinbuccal/ (accessed October 15, 2018).

[83] Park K, Kwon IC, Park K. Oral protein delivery: Current status and future prospect. React Funct Polym 2011;71:280-7.

[84] Bernstein G. Delivery of insulin to the buccal mucosa utilizing the RapidMist ${ }^{\mathrm{TM}}$ system. Expert Opin Drug Deliv 2008;5:1047-55.

[85] Modi P, Mihic M, Lewin A. The evolving role of oral insulin in the treatment of diabetes using a novel RapidMist ${ }^{\mathrm{TM}}$ system. Diabetes Metab Res Rev 2002;18:38-42.

[86] Pozzilli P, Raskin P, Parkin CG. Review of clinical trials: update on oral insulin spray formulation. Diabetes, Obes Metab 2009;12:91-6. doi:10.1111/j.1463-1326.2009.01127.x. 